\title{
A multikulturális nevelés kihívásai etnikailag változó településeken
}

\author{
Kocsis Péter Csaba
}

\begin{abstract}
Challenges of multicultural education in ethnically changing settlements Abstract

Providing equal education opportunities is a fundamental challenge for the local education system in multi-ethnic settlements. Fair education and multicultural education are influenced by demographic change, especially by the rise of the Roma population in Transylvanian settlements nowadays. The aim of this study is to examine the pedagogical challenges caused by the increasing number of Roma pupils in the schools in Gencs, Ákos, and Zabola. The research focuses on the possibilities of the multicultural education in the Hungarian language-based classes in elementary schools: how can teachers support children in a multicultural environment. In my study I present a review about the Roma pupils' education in Hungarian language-based classes in the three settlements. The investigation is based on fieldwork made in the settlements last years.
\end{abstract}

Keywords: Gencs; Ákos; Zabola; Roma minorities; multicultural eduction

Kulcszavak: Gencs; Ákos; Zabola; roma kisebbség; multikulturális nevelés

Subject-Affiliation in New CEEOL: Social Scienses - Education - School Education

DOI: $10.36007 /$ eruedu.2021.4.55-71

A multikulturális nevelés lehetőségének kelet-európai megjelenése a rendszerváltás körüli időszakra datálható. Az oktatási rendszer demokratizálódása magával hozta a nemzetiségek oktatásának változását is. Az oktatásszervezés mellett lényeges kérdés volt, hogy mi legyen az oktatás tartalmával, ha szükséges azt változtatni, akkor ez hogyan történjen meg. A változás az iskolák demokratizálódását és az esélyegyenlőségi szempontok érvényesülését hozta magával. Emellett azonban több országban kérdés volt, hogy a nemzetiségek oktatása miként alakul, ehhez adhatott segítséget a multikulturális nevelés eszközrendszere.

\section{A multikulturális nevelés lehetőségei és korlátai}

A multikulturális nevelés értékeként a sokszínüséget, a kultúrák pluralizmusát szoktuk kiemelni. Ebben a folyamatban a nevelés, az oktatás alapját a multikulturális társadalom adja, amely térben és időben változik, de mindig keres valamilyen választ a többség és kisebbség viszonyára, legyen az asszimiláció, akkulturáció, integráció vagy egyéb viszonyulás. Az is bizonyos, hogy az együttélés során számos 
társadalmi probléma kerül elő, ezek közül tekinthetjük egynek a nevelés-oktatás kérdését (Radtke 1997). A definitív megközelítések összefoglalását adta Banks (2014) és Csereklye (2012), kitérve a multikulturális nevelés dimenzióira: a tartalmi integrációra, a különböző tudáskonstrukciókra, az elöitéletek csökkentésére, az esélyegyenlőség biztositására, valamint az iskola kultúrájával, szervezetével foglalkozó jellemzőkre. Ezeket itt külön nem elemezzük, említésével azt a helyzetet kivántuk érzékeltetni, hogy például Amerikában, Ausztráliában, de Európában is megjelenik a több nemzetiség, több kultúra találkozásának és kezelésének a kérdése az oktató-nevelő munkában. A multikulturális nevelés egyik fontos tényezője maga a kultúra, ezen belül kiemelt szerepet kap a nyelviség kérdése. A különbözö oktatási koncepciókban előtérbe kerül a kultúra és a nyelv - mint a kultúra hordozója - megörzésének a kérdése. Az így kialakított pedagógiák egyértelműen abba az irányba mutatnak, hogy a különböző kultúrák sajátosságainak megörzése fontos feladata az iskolának.

A banksi dimenziókat csupán általánosan vizsgálva azt láthatjuk, hogy azok a plurális gondolkodás, a demokratikus elvek, az esélyegyenlőség eszméjén és a tudás elsajátításának a támogatásán nyugszanak. Leegyszerüsítve fogalmazhatunk úgy, hogy a multikulturális nevelés azon eszközök és attitüdök összessége, amelyek a tudás elsajátításának folyamatát segítik az érintettek kultúrájának sajátosságait is figyelembe véve, megértve az adott kultúrát és értelmezve a tudás létrejöttének folyamatát. A multikulturális nevelés egyes stációiban lényeges vonás, hogy az egyes társadalmi különbségekre is igyekszik reflektálni. Ezeket a különbségeket emelte ki a Delors-jelentés (1997), amelyben többek között az iskola hátrányokat fenntartó gyakorlatára hívta fel a figyelmet és arra, hogy a szegénység elmélyülése ellen is van tennivalója (Majzik 1997). Az iskola olyan közösségi tér, ahol a különböző társadalmi státuszú gyerekek és felnőttek találkoznak. Ennek megfelelően a multikulturális nevelés koncepciója szerint csökkenthetők a kisebbségi csoportok hátrányai, az egymástól való idegenkedés, és így az oktatás kohéziós erővé válhat (Torgyik -_Karlovitz 2006; Páva 2015).

A multikulturális nevelés célja tehát az egyenlő oktatási-nevelési lehetőségek biztosítása a különböző etnikai vagy nemi csoportokba tartozók, az eltérő kulturális és szociális csoportba tartozók számára. Ez a megközelítés kiszélesíti azok körét, akiket a multikulturális nevelés képes megszólítani, de egyben jelzi azt is, hogy képes mindenkit integrálni a nevelési folyamatba. Így a nevelési folyamat a diákok tudáshoz való hozzásegítését támogatja, valamint a plurális társadalom működéséhez szükséges attitüdöket is kialakitja (Banks 2001). A multikulturális nevelés a gyerekek sokféleségére adott egyik pedagógiai válasz, amelytöl megoldást remélhetünk az inkluziv iskola létrehozására. 


\section{Kelet-Európa néhány sajátossága a multikulturális nevelés szempontjából}

A multikulturális nevelés szempontjából nem elhanyagolható hogy a kelet-európai gazdasági-társadalmi-politikai tér sajátos fejlödést mutatott a 20. század közepétöl. A II. világháború lezárása után a kelet-európai tömbben kialakult ún. szocialista berendezkedés felülírta az addig megszokott társadalmi tudást és az addig kialakult viszonyrendszert. A 19. századtól népszerü nemzetállami eszme a nemzetiségek asszimilációjára és az egységes nemzetállam kialakítására törekedett. Ennek fontos eleme volt a nemzeti nyelven történő oktatás, amely mindig a többségi nemzet nyelvét, vagyis az államnyelven történő oktatást jelentette. Az I. világháborút követöen a békeszerződések hatására létrejött új államok számára ugyancsak kihívás volt a nemzetiségek jelenléte, azok oktatása, s mintegy természetes válaszként jelent meg a kelet-európai államokban az oktatási rendszeren belüli asszimilációs folyamatok fenntartása és erősítése. Ez a szemlélet változott meg a Il. világháború után, az oktatási rendszerben a nemzetiségekre is másként tekintettek. Az új rendben a nemzetiségnek nem volt szerepe, a kialakult internacionalista eszmék felülírták a nemzetiségi törekvéseket az oktatás területén is (Kozma 1993). A keleti blokk államai a területükön élő kisebbségek nagysága szerint eltérően viszonyultak e kérdéshez, de jellemzően asszimilációs törekvések figyelhetők meg az érintett országokban (pl. Magyarország, Románia, Szlovákia, Ukrajna stb.). A nemzetiségek oktatásban jellemző helyzetéről jelen tanulmány keretei között három romániai település példáján keresztül vizsgálódunk, azon belül is a romák oktatására helyezzük a továbbiakban a hangsúlyt.

A cigányság létszámát Európában 10-12 millió före, míg az Európai Unió tagállamaiban 8 millió före becsülik. Az Európai Unió tagállamaiban, Romániában, Bulgáriában, Magyarországon, Szlovákiában, Csehországban és Spanyolországban élnek nagyobb számban romák (Vajda 2012).

Általánosan tapasztalható, hogy az oktatási sikeresség és a gazdasági sikeresség között nincs összefüggés a romák életében, vagyis alacsony iskolai végzettséggel is elérhetnek gazdasági sikereket. Ugyancsak elmondható, hogy az iskolai siker és a társadalmi siker között sem fedezhető fel kapcsolat, vagyis az iskolai végzettség a romák esetében nem emeli a csoporton belüli státuszt (Forray 1998). Az európai tapasztalat szerint a romák problémái bárhol Európában általánosíthatók: az alacsony iskolai végzettség, magas munkanélküliség, rossz szociális helyzet, kedvezötlen, esetenként emberhez méltatlan lakáskörülmények, kirekesztettség, stigmatizálás a jellemző. Ennek okai között a kelet-európai régióban a rendszerváltás okozta sokkot is megfigyelhetjük, amely a roma közösségeket eröteljesebben érintette. Ebben a térségben az ipari és mezőgazdasági foglalkoztatók az 1980-as évek második felében már gazdasági problémákkal küzdöttek, amely már ekkor elindította a leépítéséket, ami a rendszerváltás utáni időszakban a térségben robbanásszerüen felgyorsult, magával hozva következményként az addig szerény, de biztos megélhetéssel rendelkező családok elszegényedését is. Ez a folyamat sokkolta a roma közösségeket, majd egész Európát is, hiszen mihelyt lehetett, a 
roma csoportok is útra keltek, s a célállomások között a nyugat-európai országok szerepeltek (Forray - Borisz 2000).

A multikulturalizmus eszméje az oktatásban hasznos, a demokratikus társadalom kialakítása szempontjából pedig különösen fontos törekvés, módszer és gyakorlat lehetne. Az is egyértelműnek tűnik, hogy a nyugat-európai és észak-amerikai gyakorlat eltér a kelet-európai gyakorlattól, hiszen utóbbi területen nem a gyarmatokról bevándorló vagy egykori tősgyökeres, de dominanciájukat tekintve visszaszoruló csoportról beszélhetünk, hanem évszázadok óta együtt élő közösségekröl van szó. A nemzeti kisebbségek sorsa az európai történelemben a nemzetállamok kialakulásától kezdődően fontos kérdés, amely a 20. században nyugvópontra ért, a világháborúkat lezáró béketárgyalások, majd az 1990-es évek gazdasági-politikai átrendeződései sok áldozat árán, de pillanatnyilag kevésbé tartják felszínen ezt a kérdést. Az európai, kelet-európai országok a nemzetiségek vonatkozásában vegyes képet mutatnak, azok számarányának függvényében különböző támogatásokat biztositanak, ide sorolhatjuk a nemzetiségi oktatás biztosítását is.

Tanulmányomban három romániai település (Zabola, Gencs, Ákos) esetében vizsgálom, hogy a helyi közoktatási intézmények, ezen belül is az iskola milyen kihívásokkal néz szembe az együttélő nemzetiségek oktatásánál. A tanulmány alapját az elmúlt években végzett terepmunkák adják, ahol elsősorban az együttélést és az ehhez kapcsolódó intézményi jellemzőket vizsgáltuk.

\section{A kutatás módszertana}

A kutatás az antropológiai terepmunka módszertanát követte, amely a közösség életében való részvételen alapult. A települések esetében fontos szempont volt, hogy a roma közösségek magyar anyanyelvűek legyenek. Ez a mindennapokban azt jelentette, hogy a roma gyerekek is az iskola magyar tagozatára jártak.

A terepkutatások mindhárom helyszínen azonos módon valósultak meg: a terepre való felkészülést követően két kutatási egységben valósult meg a kutatás. Az első egységet az anyagok feldolgozása követte, majd ezután került sor egy második kutatási egységre. Így alkalom nyilt a korábbi adatok rendszerezésére, a második kutatási egység célirányos lebonyolítására. A terepen elsősorban az interjúkészítés technikáját alkalmaztuk, az interjúalanyok körében egyaránt megjelentek a helyi közösség vezetői (pl. iskolaigazgató, polgármester, roma referens, roma mediátor, szociális szakemberek, egyházi vezetők stb.), valamint a roma családok, akik mindig segitőkészen fogadtak. Az interjúk mellett a helyi statisztikai forrásokat is igyekeztünk felkutatni, amelyek elsősorban az oktatási intézmények adataira vonatkoztak, amelyek az intézményi roma arányt dokumentálták.

A kutatás az egyes településeken eltérő időpontokban történt. A zabolai kutatás lebonyolítására 2018-ban került sor, Gencsen 2019-ben valósult meg a terepkutatás, míg Ákos esetében 2019 végén és 2020 elején került sor terepmunkára, azonban a COVID-világjárvány megakasztotta a kutatásokat.

Mindhárom település esetében azonos módszertannal történt a kutatás. A települések térbeli-nemzetiségi sajátosságait vizsgáltuk, valamint a roma-magyar cso- 
portok közötti interetnikus kapcsolatokra vonatkozó interjúkat készitettünk. Jelen tanulmányban az eredmények egyik kiemelt kérdését, az oktatás területét dolgozzuk fel.

\section{A terephelyszínek rövid bemutatása}

A romániai magyar oktatás néhány jellemzőjét a települések ismertetése előtt, csupán az említés szintjén érdemes áttekintenünk. A jelenlegi határokat kialakító békeszerződések hatására az államnyelv természetszerüleg megváltozott, de Románia már 1919-ben nemzetközi egyezményben, majd az 1923. évi 282. számú törvényben biztosította az általános jogegyenlőség és számos egyéb kisebbségi jog mellett a nemzetiségi oktatás jogát is (Portik 2012). A II. világháborút követöen a nemzetiségi oktatás lehetősége továbbra is megmaradt, az 1945-ben közzétett Nemzetiségi Statútum ugyancsak kimondta az anyanyelvi oktatás biztositását elemi, közép- és felsőfokon egyaránt (Albert 1994). A nemzetiségi, így a magyaroktatás formálisan és jogszabályi keretek között biztosított volt, azonban az oktatáspolitika törekedett a nyelvi asszimiláció erősítésére, ennek egyik eszköze az iskola tannyelvének megválasztása volt. Ez egyszerüen azt jelentette, hogy a román iskolák választásától remélhették a szülök - a hivatalos és a suttogó propaganda szerint -, hogy gyermekük sikeres életpályát járhat be. Bár ez gyakori narratíva volt és a mai napig is az, azonban az erre vonatkozó kutatások rendre rámutattak, hogy a későbbi sikeresség inkább a család társadalmi státuszától, semmint az oktatás nyelvétöl függ (Bodó 2004). A romániai magyar kisebbség általános iskolái biztosítottak voltak, azonban a demográfiai trendek miatt a magyar ajkú roma közösségek iskolai részvétele egyre nagyobb arányú lett, amely a magasabb születési rátának és a nem roma lakosság kistelepülésekröl történő elvándorlásának tulajdonítható. E keretek között értelmezendőek a kutatási eredmények.

Visszatérve a kutatáshoz, tanulmányomban három romániai település, Zabola (Zăbala), Gencs (Ghenci) és Ákos (Acâș) etnikai viszonyait és ezen jellemzők közoktatásra gyakorolt hatását vizsgálom. A három település közül kettő (Gencs, Ákos) a Partiumban, míg a harmadik (Zabola) Székelyföldön található.

A két választott terület, a mai Románia területén található Partium és Székelyföld nemzetiségi összetételét tekintve nagyobb arányú magyar és jelentős magyar anyanyelvü roma közösséget foglal magában. A Partium Románia legnyugatibb, Magyarországgal határos területe, amely magyar igazgatású terület volt története nagyobb részében (a török megszállás után a 16-17. században az Erdélyi fejedelemséghez tartozott) (Köpeczi 1986), majd az Osztrák-Magyar Monarchia részeként a Magyar Királysághoz tartozott. Az I. világháborút lezáró Trianoni békeszerződés eredményeként került Romániához. A II. világháborút kísérő II. bécsi döntés eredményeként 1940 és 1945 között ismét magyar fennhatóság alá került a terület.

Hasonló történelmi utat járt be a Székelyföldnek nevezett terület is. A területen a nemzetiségek megoszlása a magyarok többségét jelzi, vélhetően az évszázados roma-magyar együttélésnek tulajdonítható, hogy a roma közösségek anyanyelve is jellemzően magyar. Székelyföld Erdély (Transylvania) területén található, a mai Ko- 
vászna, Hargita, Maros megye egy része, Fehér és Kolozs megyék egy-egy kisebb része sorolhatók ide. A nemzetiségi arányok tekintetében még ma is jelentős a magyar többségü területek száma, amely a magyar nyelvű közigazgatást és oktatást tartja fenn (Elekes 2011).

A kiválasztott települések népessége 1000 és 3300 fő között változik. Zabola a legnépesebb, ahol a 2011-es romániai népszámlálás idején cirka 3300 fő élt, ezt követi Ákos, ahol 1934 fö élt, a legkisebb település Gencs, ahol 1176 fö élt. A települések a lakosságszámot tekintve kistelepülések. Közös jellemzőjük, hogy a településeken vegyes etnikumú lakosság van jelen, így a többségi magyar nemzetiség mellett megtalálhatóak a románok, valamint a romák is. A települések nemzetiségi adatai tekintetében a népszámlálási adatok némi bizonytalanságot mutatnak: a magyar és a román nemzetiség esetében megbízhatónak tekinthetjük az adatokat, míg a romák esetében biztosak lehetünk abban, hogy az adatfelvételek pontatlanok. A népszámlálások adatai a romákra vonatkozóan Romániában is, hasonlóan, ahogyan azt például Magyarországon is tapasztalhatjuk, jelentösen torzithatnak. Az önbevalláson alapuló népszámlálás számottevően alacsonyabban méri a romák létszámát (Szilágyi 2016; Pénzes et al. 2018; Erdelystat 2, 2020). Ennek oka elsődlegesen a szabad identitásválasztában kereshető, amely a népszámlálások esetében a származástól függetlenül az önbevallás szerint regisztrálja a nyilatkozót. A nemzetiségi adatokat vizsgálva Zabolán a magyar lakosság az összlakosság 59\%-a volt (1958 fö) 2011-ben, a románok tették ki a település lakosságának 26\%át (862 fö), és romának a lakosság 11,9\%-a vallotta magát. Az itt megjelenő kb. 3\%-os deficit vélhetően a roma csoport számát gyarapítja, de látnunk kell, hogy a településen a romák arányát magasabbra, legalább 20-25\%-ra becsülik a helyi vezetők. A magasabb arányok a helyi demográfiai trendeknek tudhatók be, a nem roma fiatalok településröl való elköltözése, valamint a magyar anyanyelvű nem roma népesség alacsonyabb gyermekvállalási hajlandósága a helyi tudásban korábban megjelenik, mint a népszámlálási adatokban.

Ákos és Gencs hasonló képet mutat. Ákoson az összlakosságból 827 fö $(43,9 \%)$ vallotta magát magyarnak, a román nemzetiségűek aránya mintegy $17,6 \%$ (341 fö), míg a romák aránya 36,6\% (708 fö) volt. Gencs esetében a magyarok aránya $60,7 \%$ (714 fö), a románoké 24,2\% (289fö), míg a romáké 12,5\% (147 fő).

A kutatás szempontjából fontos megjegyezni, hogy a településeken élő romák statisztikai, a helyi becslésen alapuló és a közoktatási intézményekben megjelenő létszáma eltér egymástól. A népszámlálási adatokat megfigyelve a roma kisebbség létszáma és aránya jelentős növekedést mutat a 20. század második felétől kezdődően a vizsgált településeken (Szilágyi 2016). Ákos esetében például az 1930as népszámlálási adatok csupán 117 fő romát regisztráltak, ez 1977-ben 293 fö, 1992-ben 462 fő, 2011-ben pedig 708 fő vallotta magát romának a teljes lakosságon belül. Gencs esetében a rendelkezésre álló adatok szerint a 2002-es és 2011-es népszámlálási adatok között látunk hirtelen emelkedést, 34 föröl 147 före emelkedett a magukat romának vallók száma. Zabola esetében 1941-ben 76 fö, 1977-ben 103 fö, 1992-ben 190 fő, 2002-ben 221 fő, míg 2011-ben 398 fő vallotta magát romának (Varga 2004). 
A népszámlálási adatok roma adatainak torzitása mellett a településeket egyaránt jellemzi a szegregátumok jelenléte. A romák a településeken belül etnikailag elkülönülő telepeken, településrészeken élnek, az itt élö lakosság alacsonyan iskolázott és rendszeres jövedelemmel nem rendelkező csoportot jelent. A vizsgált települések roma közösségei ilyennek tekinthetőek, bár eltérö térbeli szegregációs mintákat mutatnak, ahogy ez lentebb részletesen bemutatásra kerül.

\section{A romák térbeli elkülönülésének jellemzői az egyes településeken}

\section{Zabola}

Zabolán a falu térszerkezetében a roma csoport hármas térbeli megjelenése tapasztalható. A roma közösség legszegényebb rétege az úgynevezett dombi romák csoportjába tartozik. Ök a falu perifériáján élnek, a dombon, ahol csak minimális infrastruktúra, az elektromos áram biztosított néhány, a falu utcáihoz közelebb eső házban. A vezetékes víz és egyéb közmüvek hiányoznak, valamint nincs kiépített út sem. Az itt élök megélhetését jellemzően a szociális transzferjövedelmek és a különböző alkalmi munkák biztosítják. A gyerekek iskolai részvétele esetleges, jellemzően ők a kimaradók csoportját alkotják.

A második, népesebb csoport a dombaljai romák csoportja. Ök a hegyről a faluszéli utcákba költöztek, jól körülhatárolhatóan az egykor románok által lakott, a román temetőt övező utcák adtak lehetőséget a dombról való leköltözésre, miután az ott élö családok a románok által lakott területre költöztek. Az itt lévő lakások a parasztházak jellemzőit mutatják, a kialakításuk, bővítésük egy-egy család anyagi helyzetéröl is árulkodik, ami esetenként hozzáépítést, kisebb kertet és állatok tartásához szükséges épületeket foglal magába. A lakások infrastruktúrája illeszkedik a falu átlagához, bár pormentes utcák nincsenek, az áram, vezetékes víz, valamint egyéb szolgáltatások, mint például a kábeltévé elérhetőek. A családok zöme dolgozik, többen hivatalos foglalkoztatásban alkalmazottak, de több család esetében a helyi önkormányzat által biztosított közmunkaprogram és az ehhez társuló szezonális gyűjtögető munka (gomba, áfonya szedése és értékesítése) társul, valamint napszámos munkából tartják fenn magukat.

A harmadik csoport a falusi romák csoportja. Ök azok, akik az 1989-es romániai forradalom utáni időszakban gyorsan alkalmazkodni tudtak a megváltozott politikai-gazdasági környezethez. Kereskedni kezdtek, amelyböl nagy haszonra tettek szert, és ebből jelentős összegeket költöttek presztízsjavak fogyasztására. Ezek közül kiemelkedett a falu föutcáján vásárolt vagy épített emeletes ház, amely kitünik és eltér a korábbi építészeti gyakorlattól. A falu föutcáját korábban hagyományosan a magyar közösség lakta, a romák megjelenése újszerü jelenség volt az 1990-es években. 


\section{Gencs}

A gencsi romák is szegregált településrészen élnek a falun belül. A romák a település északi részén, a fő utcáról merőlegesen nyíló, a településhatár felé vezető utca végén telepedtek le az 1960-as években.

Korábbi lakóhelyük illeszkedett egykori foglalkozásukhoz, a fö út mentén, de a település perifériáján éltek, ahol vályogvetéssel foglalkoztak. Az 1960-as években a mezőgazdasági termelés racionalizálásának indoka mentén a romák egykori lakóhelye felszámolásra került, a vályogvetés a helyi szövetkezetben folytatódott. A racionalizálás eredménye a roma családok számára új lakóhely kijelölését eredményezte, amely szintén a település perifériáján található. Új helyükön kölcsönböl és a helyi termelőszövetkezet segítségével építettek új, szoba-konyhás lakásokat. A ma ott élő roma közösség bár szegregált körülmények között él, mégsem mutatja a mélyszegénységben élök általános jellemzőit. A családok többségében a családfő dolgozik, rendszerint lakóhelytöl távoli munkavállalással (Szuhay 1999), jellemzően az építőiparban és a mezőgazdaságban dolgoznak. Az építőipari munkák egy része országon belül érhető el, míg egy mobilabb csoport a magyarországi munkavállalást részesíti előnyben. Mindkét csoport jellemzője, hogy vállalkozóként, érdekeiket képviselve tudnak megjelenni a munkaerőpiacon, és jellemzően 1990 óta folyamatos ez a munkavállalási stratégia. A mezőgazdaságban dolgozók célállomása szintén Magyarország, ők a határ menti településeken vállalnak mezőgazdasági bérmunkát, ez többnyire szezonális munkavállalást tesz lehetővé és ebböl tartalékolnak a szezonon kívüli időszakra. A gencsi telep képe a megszerzett jövedelmeknek köszönhetöen folyamatosan változik. Az egykori szoba-konyhás házak bővülnek, esetenként a helyükre új, modern házak épülnek. A közösség belső rétegződése is elindult, de ez csupán néhány esetben párosul térbeli helyváltoztatással, a faluba történő beköltözéssel. Az itt élők anyagi reprezentációja a településrészen a házak nagyságában, díszítettségében és a megszerzett anyagi javak formájában (modern gépkocsi, gyerekeknek drága játékok stb.) valósul meg.

\section{Ákos}

Ákos esetében a változást szintén a rendszerváltás hozta. A 16. századtól jelentős református közösségének fogyatkozása, elöregedése az utóbbi 30 évben egyre inkább jellemzi a települést. Az itt élő roma közösség a szegregált élethelyzetek egy újabb típusát jelenti, hiszen az egykori cigánytelep a temető melletti vályogos tó közeléből folyamatosan a falu szélső, egykor parasztcsaládok által lakott településrészére költözött. A folyamat tipikusnak tekinthető, hiszen az elöregedő magyar lakosság eladta a házakat, a gyermekek jellemzően a közeli városokban keresték a boldogulásukat, így az egykori ingatlanok eladóvá váltak. Ez a terület leértékelödését is magával hozta, hiszen a romák beköltözése felgyorsitotta a folyamatot, egyre gyorsabban és egyre olcsóbban kerültek az ingatlanok eladásra. A település szélén elhelyezkedő három utca, valamint a fö útról leágazó utca ma a romák jellemző lakóhelye. A településrészen belül megfigyelhető különbség az egyes utcák között. A 
legkedvezőtlenebb helyzetben az ún. Legelő utca van, ahol kisebb és rosszabb állapotú lakások vannak, mint a többi utcára jellemzö átlag. Itt élnek a legszegényebb családok, ők azok, akik jellemzően transzferjövedelemből tartják fenn magukat.

A roma közösség többsége föként a lakóhelytől távoli munkavállalás stratégiáját követi (Szuhay 1999), ennek célállomása Magyarország, és inkább a mezőgazdasági bérmunka jellemzi. A megszerzett jövedelmet sok esetben itt is az ingatlanok bővitésére, új lakások építésére fordítják. Az utóbbi időben néhány család a falu központi részeire költözött, de ez nem jelent tömeges mobilizációt. Ezekben az esetekben elöfordult az is, hogy a családtagok, a rokonok is követték, így a faluban egy-egy házsor, több szomszédos ingatlan ugyanazon család tulajdonában van. Ezek a családok jellemzően a romániai építőiparban dolgoznak vállalkozóként, aminek eredményeként tisztességes, de nem látványos gyarapodás jellemzi ezeket a családokat.

\section{Az iskolai arányokról}

Az etnikai arányok változása a közoktatási intézményekben még inkább látható változást hozott a vizsgált településeken. Az országosan jellemző demográfiai trendek, amelyek kevesebb gyermek születését, a fiatalok kistelepülésekröl történő elvándorlását jelentik, hatással vannak a közoktatási intézményekben megjelenő romák arányára is. A romák körében magasabb a gyermekszám, bár ezekben a családokban is csökkenő tendenciát mutat a gyermekvállalás az utóbbi években. A csökkenő gyermekvállalás és a közeli városok elszívó hatása az iskoláskorú népesség folyamatos csökkenését eredményezte a vizsgált falvakban. A nem roma lakosság idősödése egyaránt jellemző a magyar és a román közösségekre. Ezen kívül a roma közösség mobilitása alacsonyabb, mint a nem roma lakosságé. Esetükben az iskolai hátrányok is éreztetik hatásukat, az alacsony iskolai végzettséggel nem tudnak munkát vállalni a közeli városokban, ha esetleg mégis lehetöség nyílna erre, akkor olyan alacsonyan kvalifikált munkakört tudnak ellátni, amely nem biztosítja

a család fenntartását. A falusi környezetböl városba történő mobilitási utak tehát korlátozottak. Ez a jelenség nem csupán a vizsgált települések esetében jelenik meg, hanem Erdély területére általánosan igaz (Kocsis - Kotics 2019; Pozsony 2012; Kotics 1999).

Az iskolai adatokat vizsgálva láthatóvá válik a fenti demográfiai trendekből adódó következmény, amely az intézményekben tapasztalható magas roma reprezentációt okozza. Röviden áttekintve azt láthatjuk, hogy a zabolai általános iskolában a diákok mintegy $70 \%$-a roma, ez a felmenő osztályok esetében folyamatosan növekszik. A demográfiai trendek hatását jól mutatja az is, hogy a korábban jellemző párhuzamos osztályok helyett immár évfolyamonként egy-egy osztályban folyik az oktatás. Ez a tendencia az utóbbi 20 évben alakult így (Kocsis - Kotics 2019). A gencsi iskola esetében hasonló tendenciát figyelhetünk meg: az összes magyar tagozaton tanuló diák közül a romák aránya 70\% (Kocsis 2019). Fontos megjegyeznünk, hogy Gencs esetében a közeli városnak is jelentős elszivó hatása van, a nem roma gyerekek jelentős többsége a közeli városban végzi tanulmányait. Ákos vonatkozá- 
sában az iskolai statisztikák még nagyobb roma arányt jeleznek, ott $77 \%$ feletti volt a roma tanulók aránya az iskolában.

A romák oktatásban való részvételét vizsgálva két fontos adatot emelünk itt ki. Az egyik, hogy a romániai oktatási rendszerben a roma arány 4,9\%-os országosan, vagyis a vizsgált három település esetében a roma arány magasan az országos átlag felett van (Közoktatási helyzetkép... ). A népszámlálási adatok és ezek elemzései rámutattak arra, hogy a romániai cigány népesség egy jelentős része nemzetiségi hovatartozását tekintve ugyan romának, de anyanyelvét tekintve magyar anyanyelvünek vallotta magát (Szilágyi 2016; Kapitány 2013). A vizsgált településeken a roma közösség anyanyelve tehát magyar, amely egyúttal azt is jelenti, azon 4,9\%nyi tanuló közé tartoznak, akik a romániai oktatási rendszerben magyar tagozaton folytatják tanulmányaikat ( $\mathrm{A}$ romániai magyar iskolahálózat...).

\section{A multikulturális nevelés néhány jellemzője a roma közösségekben}

A romániai, szükebben az erdélyi romák a multikulturális környezetben sajátos helyzetben vannak. A sajátosságot jelen összefüggésben az adja, hogy minden országban etnikai kisebbségként kezelték a romákat, és mivel nem volt anyaországuk, így - ennek is köszönhetöen - érdekérvényesítő képességük alacsony volt. Ez is okozhatta, hogy az 1990-es évekig nem születtek nemzetközi megállapodások a kultúrájuk támogatására vagy oktatási intézményrendszerük kiépítésére vonatkozóan. Ez a sajátosság köszönhetö annak is, hogy a roma csoportok a lokális közösség többségi csoportjaihoz hatékonyan alkalmazkodtak a történetük folyamán, így anyanyelvük sok esetben a többségi közösség anyanyelvét követi, s így - ahogyan arra a népszámlálási adatok elemzései is rámutattak - a magyar többségü területeken jellemzően a magyar csoporthoz hasonultak (Tátrai 2011). Ez a tény alapvetően változtatta meg az oktatás területén tapasztalható arányokat, ahogyan arra a három település esetében rámutattunk. A roma közösség jellemzőit általánosan vizsgálva egyértelműen látható volt, hogy a kelet-európai régióban a rendszerváltás után válnak igazán láthatóvá a romák. Az élet legtöbb területén azonban elsősorban a hátrányok váltak érzékelhetővé számukra. A rendszerváltás előtt a roma csoportok alacsonyan kvalifikált munkakörökben dolgoztak ugyan, de egy viszonylagos kiszámítható jövedelemmel rendelkeztek, amelyet esetenként egyéb jövedelmekkel egészitettek ki. Ez a rend változott meg a forradalom után, és vált egyre inkább láthatóvá a szakemberek és a politikai szereplők részére egyaránt. Egyre jellemzöbb lett a romák iskolai kudarca, melynek okai között a sikertelenséget, az iskolai lemorzsolódást, a szocializációs hátrányokat stb. egyaránt megemlithetjük (Forray - Hegedüs 1998). Kevesebb szó esik arról azonban, hogy az iskolai elvárások hogyan illeszkednek a roma közösségek sajátosságaihoz, hiszen az iskola azokat a középosztálybeli normákat közvetíti, amelyek mentén az iskola funkcióit, feladatrendszerét meghatározták. Az iskola jutalmazó rendszere kevésbé tudja dijazni azokat az ismereteket, kompetenciákat, amelyek a roma gyerekeknél 
megvannak, hiszen azok nem illeszkednek a kérdésekre válaszoló, fegyelmezett diák ideáljához. A terepkutatások során az iskolaigazgatókkal, tanárokkal készített interjúkból kirajzolódott, hogy az iskolai elvárásoknak a roma gyerekek nem tudnak megfelelni. A családban nem tudnak a szülők segítséget adni a tanulásban, sokszor nem adott otthon a tanuláshoz optimális környezet, vagyis nincs a gyereknek külön szobája, íróasztala: egyszóval nem adottak a nyugodt tanuláshoz a körülmények. Ebből adódik, hogy a család és az iskola között az iskolai teljesítmény miatt konfliktusos helyzetek alakulnak ki. Ezt erősíti sok esetben, hogy a szülök külföldi munkavállalása miatt a gyerekeken lévő kontroll kisebb, így a tanulás hiányosságai mellett a hiányzások is terhelik a család és az iskola közötti viszonyt. Probléma a roma gyerekek lemorzsolódása is, de az iskolából való kimaradásnak számos oka lehet, például, hogy a család összetartása jellemzően a nőkre, míg a külső ellátása a férfiakra hárul. A roma családok esetében tapasztalható munkavállalási stratégiák szintén az iskolai hiányzásokat növelik. A külföldi munkavállalás esetében a kisgyermekes családok elmondták, hogy több hónapra mennek el külföldre, a kisgyermeket nem tudják, nem akarják otthon hagyni. Ez 5 éves korig különösebb problémát nem okoz, de az iskola előtt kötelező egy évet eltölteni az óvodában, majd az iskolai oktatás a 0 . osztályban történik, amely a hátrányos helyzetü gyermekek felzárkóztatását hivatott segíteni, ezzel csökkentve a szociokulturális különbségek okozta hátrányokat. A kötelező oktatás kimeneti oldalán azt tapasztalhatjuk, hogy a fiatalok a 8. osztály után kimaradnak a líceumokból, vagyis nem végzik el a 10. osztályt. Többen már korábban lemorzsolódnak és a 8 . osztályt sem végzik el. A pedagógusok szerint ezeket a gyerekeket nehéz nyomon követni, és még nehezebb az iskolai oktatás keretei közé reintegrálni. Ugyancsak életkori sajátosságként jelenik meg, hogy serdülökorban már részt tudnak venni a családi munkamegosztásban, így a munkavállalásban ők is érintettek lesznek. A megkeresett jövedelem sok esetben lényegesen magasabb, mint a helyi értelmiség bérezése, így a tanulás feltételezett hosszú távú megtérülése nem jelenik meg szempontként az oktatással kapcsolatos döntések meghozatalánál.

Legyen azonban bármi is az oka, a végeredménye mobilizációs kudarcnak tekinthetö, amely alapját az a kulturális minta adja, amely gátolja a klasszikusnak tekinthető társadalmi mobilizációt, általában és helyi szinten is (Szolár 2006).

\section{A multikulturális nevelés kihívásai a vizsgált településeken}

A multietnikus jellemző a lokális világokban túlmutat az egyszerü létszámadatokon, felveti a politikai befolyás kérdését, valamint a helyben meglévő közszolgáltatások megszervezésének módját is. A három település esetében azt láthattuk, hogy az oktatás alapbázisát a magyar anyanyelvü és a magyar tagozatokon tanuló roma diákok adják. Ebben a helyzetben felmerül a kérdés, hogy a nevelés hogyan tud alkalmazkodni a változó keretekhez, vannak-e válaszok az etnikai átrendeződésre. A multikulturális nevelés minden szegmensére nem tudunk kitérni, vizsgálatunk az etnikai átrendeződésre és az ebből adódó kérdésfelvetésre irányul, így az intézmények szakmai müködését, a multikulturális nevelés minden szegmensének vizs- 
gálatát nem tudjuk megtenni, annak ellenére, hogy a tanulók értékelése legalább annyira fontos a folyamatban, mint magának a multikulturális nevelésnek a céljai.

A multikulturális neveléssel kapcsolatos törekvések között az asszimiláció, a tolerancia, a kooperáció és a társadalom megváltoztatására irányuló folyamatokat, jelenségeket említik a szakemberek (Banks 2001; Páva 2015; Torgyik - Karlovitz 2006). Ha az egyes dimenziókat a három település jellemzőinek rendszerében próbáljuk értelmezni, akkor arra jutunk, hogy a többség esetében oly népszerü aszszimilációs törekvések a fentebb vázolt etnikai arányok esetében a konkrét településeken nem tudnak érvényesülni. Van ugyan egyfajta törekvés a domináns magyar csoport esetében, hogy a romák a többségi életmódot folytassák, ez azonban a családok egyedi döntése alapján valósul meg. A multikulturális nevelés nemzetközi gyakorlatában ezt a folyamatot a kisebbségi csoport nyelvi képzése segíti, amely célja, hogy felzárkóztassa a többségi kultúrához a kisebbségi csoport tagjait. Esetünkben ez a folyamat irreleváns, hiszen láthattuk, hogy a roma csoportok a többségi csoporthoz hasonlóan magyar anyanyelvüek. A két csoport közötti különbség azok társadalmi státuszából következik, vagyis a roma csoport a szegénység kultúrájával írható le. A romák és nem romák közötti kapcsolat a településeken belül korlátozott, annak ellenére is, hogy a korábbi időszakban a mezőgazdasági munka során alakultak ki alkalmi foglalkoztatások.

Az iskolai környezetben a roma kultúra oktatásáról, annak megörzéséről nincs szó. A magyar tagozaton továbbra is az általában elvárt tananyag átadása, megtanítása, klasszikus számonkérése a mérvadó, a helyi tantervekben, tanítási gyakorlatban nem jelennek meg az eltérö kulturális mintázatok. Ennek megfelelően a multikulturális oktatásban megjelenő tolerancia elve is korlátozottan tud érvényesülni, mert a roma kultúra ezeken a településeken nem mint a kulturális sokszínüség egyik szegmense jelent meg, sokkal inkább a szegénység kultúrájával volt azonosítható (Ladányi - Szelényi 2004).

Az utóbbi évtizedek gazdasági folyamatai a roma közösségek számára az anyagi helyzet javulását hozták, a roma gyerekek jelenléte az iskolákban nőtt, az iskolák azonban nem tudtak alkalmazkodni a megváltozott tanulói összetételhez. A pedagógusok narratíváiban a roma gyerekek elsősorban szocializációs hátrányként, az iskolai szabályokkal kapcsolatos normasértésként, család és iskolai közötti konfliktusként jelennek meg. A pedagógusok interjúi alapján az iskolai hiányzások jelentik a legfőbb problémát. Ezek jellemzően a család külföldi, jellemzően magyarországi munkavállalására vezethetők vissza. Ebben a helyzetben a kooperáció módszerének alkalmazása is kérdéses. A kooperatív technika módszertanként megjelenhet a tanórák gyakorlatában, azonban a multikulturális területen megfogalmazott célját, a különböző kulturális és társadalmi csoportok közötti együttmüködést, az iskolai arányok eltolódása miatt nem tudja biztosítani.

A multikulturális nevelés irányzatai közül talán a társadalomalakitás igénye és funkciója jelenhet meg az iskolában, mint tartalom. A roma közösségek befolyása a településeken a létszámbeli gyarapodással egyre nagyobb. A helyi közösségek számára alapvető kérdésként jelenik meg, hogy a roma közösségek identitása miként alakult. A felnövekvő generációk magyar nyelvü iskoláztatása a roma közösség által tartható fenn, így a romák magyar, vagy roma-magyar identitásának 
erősítése, megőrzésének támogatása az intézményes keretek eszközeivel is fontos lehet. A magasabb iskolai végzettség jelenleg még nem jelenik meg mindennapi értékként a településeken, leginkább a hosszú távú stratégiai gondolkodás és a rövid távú haszon konfliktusa (Bernstein 1961, idézi Meleg 1996) figyelhető meg mindhárom településen. Az iskola mint a társadalmi mobilitás potenciális csatornája a maga értékrendjével igyekszik közvetíteni a tanulás, a végzettség és a késöbbi munkavállalási potenciál fontosságát. A roma családok mindennapjai, a megélhetési stratégiák, a külföldi munkavállalás a családokban a roma gyerekeket már a korai életszakaszban, akár már kiskamasz korukban a munkavállalás irányába, a munkaerő áruba bocsátása és a megszerezhető jövedelmek maximalizálásának irányába terelik. Ez a gyakorlat pillanatnyilag felülírja az oktatás törekvéseit, amelynek fókusza a gyermekek hosszas iskolázására és legalább egy szakma/képesítés megszerzésére esik.

Felmerül a kérdés, hogy ebben a helyzetben az iskolának milyen lehetőségei vannak. Az oktatás, az oktatási eredményesség a helyi magyar közigazgatás minden intézménye számára fontos, hiszen a roma közösségek a magyar dominancia fenntartása mellett az intézményekben, iskolákban dolgozók számára egzisztenciális függést is jelentenek egyben. A demográfiai adatok mindhárom településen azt vetítik elöre, hogy a következö években még akkor is emelkedik majd a roma gyerekek száma az óvodákban, iskolákban, ha a roma arány miatt a nem roma tanulók más településre történö vándorlása csökken vagy esetlegesen megáll. Utóbbira kicsi az esély. Kérdés, hogy az iskola keretei, az oktatás tartalma, a formális szabályok alakithatóak-e a tapasztalt sajátosságokhoz, vagy a szabályozás merev és nem teszi lehetővé a gyerekek és családok gyakorlatához való illeszkedést. A három település esetében láthattuk, hogy a problémák összetettek, megjelenik szociális, szocializációs probléma a településeken. Eltérő mértékben ugyan, de elindult a roma közösség belső átstrukturálódása is. Ez alakítja a helyi társadalmon belül kialakult hierarchiát, az anyagi helyzetet, az egyes csoportok fogyasztását. Mondhatjuk, elindult a roma polgárosodás, amely esetében kérdés, hogy az oktatás, a tudás bekerülhet-e a presztízsjavak fogyasztása közé, vagy a rövidtávú, elérhető jövedelem alapú szemlélet dominanciája marad érvényben a roma közösségekben.

\section{Konklúzió}

Összefoglalva: a tanulmányban arra kívántunk rámutatni, hogy a magyar ajkú roma kisebbséget is magukba foglaló településeken sajátos jellemzők figyelhetők meg a magyar nyelvü oktatást végző intézményekben. A három vizsgált település tapasztalatai azt mutatták, hogy a magyar tagozaton többségében magyar anyanyelvü roma gyerekek tanulnak.

A népszámlálási adatok és az egyéb, romákra vonatkozó felmérések egyértelmüen mutatják, hogy a magyar többségü településeken, főként azokban a falvakban, ahol a magyar ajkú romák több, mint 40\%-a él, a születési ráta emelkedik és ez a tendencia várhatóan megmarad. Ez a trend az iskolákban is érezteti hatását, várható, hogy a kistelepülések magyar tagozatain egyre több roma tanuló jelenik meg 
Romániában. A három település esetében azt láthattuk, hogy a roma közösségek belső differenciálódása elindult, ennek a lehetőségét a rendszerváltás adta meg. Az oktatás, ezen belül a magyar tagozatok helyzete kettős kihívás elött áll, hiszen az oktatási intézményeket is fenntartva a (szak)politikai érdekérvényesités területén is helyt kell állni: a magyar tagozatok fenntartása a romániai, szűkebben az erdélyi magyar közösség fennmaradásának egyik kulcskérdése. Másrészről azonban a roma közösségek integrálása, a 2000-es éveket követően egyre sürgetöbb feladat az Európai Unió tagországaiban. A Roma Integráció Évtizede 2005-2015 programhoz Románia is csatlakozott, amely többek között az oktatás, a lakhatás, az egészségügy, a foglalkoztatás javítása és a jogvédelem területén igyekezett kormányzati beavatkozásokat elindítani. Ezt követte a romániai roma stratégia 2011-ben, majd 2015-ben, amely az oktatás, a foglalkoztatás, az egészségügy, a lakhatás, a kultúra és szociális szolgáltatások szolgáltatásfejlesztése állt (Strategy of the... 2015).

A multikulturális oktatás területén így alapvető kérdésként jelenik meg, hogy a multikulturális nevelés bevezetéséhez vezető lépések miként illeszthetők be a mindennapi gyakorlatba. A tantervi tartalmak átalakitása általánosan a kisebbségi csoportok kultúrájának megismerését, azok értékeinek közvetítését is szolgálja. Jelen esetben a roma közösség is jelentős mértékben a magyar kultúra hordozója, így kérdéses, hogy milyen tartalmak jelenjenek meg a tananyagban, milyen módszerek kerülnek alkalmazásra. A gyerekek teljesítménynövelése fontos kérdés lehet, ebben alapvető kihívás elött a pedagógusok vannak. A kérdés a gyerekek tudáskonstrukciós folyamatának a feltárása, ennek megértése és az oktatási módszerek ilyen irányú átalakítása. Ennek a módszertannak a kiszélesítése javíthatja az iskolai sikerességet, és esélyt adhat arra, hogy a településeken esetenként tapasztalható nem roma csoport elvándorlása csökkenjen (Gencs). Az iskola így új minőségi szolgáltatás biztosítására lenne képes, és tanulói megtartó erejének növekedésével a csoportközi interakciók is növelhetök lennének, ahogyan ennek fontosságára a multikulturális neveléssel kapcsolatban felhívják a figyelmet (Páva 2015).

A multikulturalizmusról való diskurzus eltérő hangsúlyokkal jelenik meg az országok oktatási gyakorlatában. A nyugati, amerikai példák más alapról indultak el, mint a kelet-európai gyakorlat. Tanulmányomban arra kívántam rámutatni, hogy a demográfiai folyamatok, a roma közösségek megélhetési stratégiái, szociokulturális sajátosságai stb. mind befolyásolják az intézményi helyzetet, az ott kialakítandó oktatási gyakorlatot. A romániai helyzet e kérdéskörben még bonyolultabb, hiszen a roma közösségek jelentős részének magyar kultúrához való kötődése egyértelmü (nyelviség, a szokásrendszer elemei), viszont a közösség sajátosságaira az intézmény nem tud reflektálni. Ide sorolhatjuk például a tapasztalt szocializációs hátrányokat, a megélhetés okozta magas iskolai hiányzásokat, vagy a társadalmi státuszra visszavezethető hosszú távú stratégiai gondolkodás hiányát. Ez a helyzet az iskolai értékek, az oktatott tartalmak, az iskola eddigi müködési gyakorlatának felülvizsgálatát igényli, amely a diákok sikeressége mellett magának az iskolának a megmaradását is eredményezheti.

A multikulturális oktatás a vizsgált esetekben lehetőségként és nem a romániai oktatásban megjelenő alkalmazott módszertanként jelent meg. Egyes elemei ugyan beépültek a vizsgált települések iskolai gyakorlatába, de a komplex rendszer 
nem került bevezetésre, így ez lehetőségként áll a magyar tagozatokon oktatott roma gyerekek számára.

\section{Irodalom}

Albert Dávid (1994): A romániai magyar oktatás, 1945-1989. Iskolakultúra 4/8., 21-30.

Banks, James A. - Banks, Cherry A. McGee (2001): Handbook of Research on Multicultural Education. San Francisco: Jossey-Bass.

Banks, James A. (2014): An Introduction to Multicultural Education. Fifth edition. Seattle: University of Washington.

Bernstein, Basil (1961): Nyelvi szocializáció és oktathatóság. In: Iskola és társadalom I. Szerk. Meleg Csilla. Pécs: JPTE Tanárképző Intézet, 131-150.

Bodó Julianna (2004): Egy asszimilációs kísérlet kudarca. Az iskola nyelvének megválasztása a Székelyföldön a hatvanas-hetvenes években. In: Kisebbségi kultúrák. Szerk. Kocsis Péter Csaba. Budapest: Zsigmond Király Főiskola, 227-243.

Cs. Czachesz Erzsébet (2007): A multikulturális neveléstöl az interkulturális pedagógiáig. Iskolakultúra 16/8-10., 3-11.

Delors, Jacques (1997): Oktatás - rejtett kincs. A Jacques Delors vezette nemzetközi bizottság jelentése az UNESCO-nak az oktatás XXI. századra vonatkozó kérdéseiről. Budapest: Osiris.

Elekes Tibor (2011): Székelyföld közigazgatás-földrajzi változásai a 13. századtól napjainkig. Földrajzi Közlemények 135/4., 415-429.

Forray R. Katalin - Hegedüs T. András (1998): Cigány gyermekek szocializációja. Budapest: BME.

Forray R. Katalin - Szegál A. Borisz (2000): A cigány gyermek Kelet-Európa iskoláiban. Educatio 9/2., 291-303.

Forray R. Katalin (1998): A cigányság oktatásának egyes kérdései Európában. Magyar Pedagógia 98/1., 3-16.

Kapitány Balázs (2013): Kárpát-medencei népszámlálási körkép. Demográfia, 56/1., 2564.

Kocsis Péter Csaba - Kotics József szerk. (2018): Cigány-magyar együttélés Zabolán. Debrecen: Didakt Kiadó.

Kocsis Péter Csaba szerk. (2019): A gencsi cigányoknak nincs párja. Debrecen: Didakt Kiadó.

Kotics József (1999): Integráció vagy szegregáció? Cigányok a háromszéki Zabolán. Korunk 10/9., 75-83.

Kozma Tamás (1993): Etnocentrizmus. Educatio 1993/2., 195-210.

Köpeczi Béla föszerk. (1986): Erdély története I-III. Második kötet 1606-tól 1830-ig. Budapest: Akadémiai.

Ladányi János - Szelényi Iván (2004): A kirekesztettség változó formái. Budapest: Napvilág Kiadó.

Majzik Lászlóné (1997): Oktatás - rejtett kincs. Delors-jelentés a XXI. századi oktatásról. Új Pedagógiai Szemle 1997/11., 3-17. 
Páva Rita (2015): Interkulturális, multikulturális oktatás alapjai. Budapest: ELTE.

Pénzes János - Tátrai Patrik - Pásztor István Zoltán (2018): A roma népesség területi megoszlásának változása Magyarországon az elmúlt évtizedekben. Területi Statisztika, 2018, 58(1): 3-26.

Portik Erzsébet (2012): Erdélyi magyar kisebbségi sorskérdések a két világháború között. Iskolkultúra 22/ 9., 60-67.

Pozsony Ferenc (2012): Zabola. Egy polgárosult falu kulturális öröksége. Sepsiszentgyörgy: Háromszék Vármegye Kiadó.

Radtke, Frank-Olaf (1997): Az idegenség konstrukciója a multikulturalizmus diskurzusában. In: Multikulturalizmus. Szerk. Feischmidt Margit. Budapest: Osiris Kiadó, Láthatatlan Kollégium, 39-46.

Szilágyi Ferenc (2016): Roma népesség a partiumi határmegyékben (Bihar, Szatmár) In: Roma népesség Magyarország északkeleti határtérségében. Szerk. Szilágyi Ferenc Pénzes János. Nagyvárad: Partium Kiadó, 49-90.

Szolár Éva (2006): Az oktatási exklúzió, a társadalmi-gazdasági kirekesztődés és a „,bezáródott" mobilitási csatornák. Magyar Pedagógia 106/3., 187-213.

Szuhay Péter (1999): Foglalkozási és megélhetési stratégiák a magyarországi cigányok körében. In: A cigányok Magyarországon. Szerk. Kemény István. Budapest: MTA, 139-160.

Tátrai Patrik (2011): Anyanyelv és nemzetiség mint az interetnikus kapcsolatok mutatója Erdély magyar lakosságának példáján. Tér és Társadalom 25/2., 48-68.

Torgyik Judit - Karlovitz János Tibor szerk. (2006): Multikulturális nevelés. Budapest: Bölcsész Konzorcium.

Vajda Györgyi (2012): Romapolitika az EU-ban. In: Az Európai Unió szociális politikái. Szerk. Sziklai István. Budapest: ELTE-TÁTK, 165-176.

Varga E. Árpád (2004): Erdély etnikai és felekezeti statisztikája. Népszámlálási adatok 1850-2002 között. Csíkszereda: Pro-Print Kiadó.

\section{Internetes források}

ÁKOS népszámlálási adatok. Online: https://nepszamlalas.adatbank.transindex.ro/?p$\mathrm{g}=$ etnikai\&id=2144

A romániai magyar iskolahálózat szerkezete. Online: http://statisztikak.erdelystat.ro/cikkek/a-romaniai-magyar-iskolahalozat-szerkezete/67 (Letöltés: 2021.03.14.)

Csereklye Erzsébet (2012): A tanulói sokféleség és a tanárok multikulturális nézetei. Doktori disszertáció, kézirat. Online: https://ppk.elte.hu/file/Csereklye_Doktori-dolgozat. pdf (Letöltés: 2021.04.30.)

Erdelystat 1 (2021): A romániai magyar iskolahálózat szerkezete. Online: http://statisztikak.erdelystat.ro/cikkek/a-romaniai-magyar-iskolahalozat-szerkezete/67 (Letöltés: 2021. 03.26.)

Erdelystat 2 (2020): Magyarul beszélő romák Erdélyben. Területi elhelyezkedés és lakóhelyi szegregáció. Online: http://statisztikak.erdelystat.ro/cikkek/magyarul-beszel-romak-erdelyben-terleti-elhelyezkedes-es-lakohelyi-szegregacio/60 (Letöltés: 2021.03.26.) 
Erdelystat 3 (2019): Közoktatási helyzetkép: a magyar nyelvü képzésben részt vevők számának és arányának alakulása 1990 és 2017 között. Online: http://statisztikak.erdelystat.ro/cikkek/kozoktatasi-helyzetkep-a-magyar-nyelvu-kepzesben-reszt-vevok-szamanak-es-aranyanak-alakulasa-1990-es2017-kozott/27 (Letölés: 2021.03.26.)

Közoktatási helyzetkép: a magyar nyelvü képzésben részt vevők számának és arányának alakulása 1990 és 2017 között. Online: http://statisztikak.erdelystat.ro/cikkek/kozoktatasi-helyzetkep-a-magyar-nyelvu-kepzesben-reszt-vevok-szamanak-es-aranyanak-alakulasa-1990-es2017-kozott/27 (Letöltés: 2021.03.14.)

Strategy of the Goverment of Romania for the Inclusion of the Romanian Citizens Belongigng to Roma Minority for 2015-2020. Online: https://ec.europa.eu/info/sites/default/ files/roma_romania_strategy2_en.pdf (Letöltés: 2021.04.24.) 